\title{
Economic analysis of alternative nutritional management of dual-purpose cow herds in central coastal Veracruz, Mexico
}

\author{
Victor Antonio Absalón-Medina - Charles F. Nicholson • \\ Robert W. Blake • Danny Gene Fox • \\ Francisco I. Juárez-Lagunes • \\ Eduardo G. Canudas-Lara • \\ Bertha L. Rueda-Maldonado
}

Accepted: 12 December 2011 / Published online: 23 December 2011

(C) The Author(s) 2011. This article is published with open access at Springerlink.com

\begin{abstract}
Market information was combined with predicted input-output relationships in an economic analysis of alternative nutritional management for dual-purpose member herds of the Genesis farmer organization of central coastal Veracruz, Mexico. Cow productivity outcomes for typical management and alternative feeding scenarios were obtained from structured sets of simulations in a companion study of productivity limitations and potentials using the Cornell Net Carbohydrate and Protein System model (Version 6.0). Partial budgeting
\end{abstract}

\footnotetext{
V. A. Absalón-Medina • R. W. Blake • D. G. Fox

Department of Animal Science,

Cornell University,

Ithaca, NY 14853, USA

C. F. Nicholson

Department of Agribusiness,

California Polytechnic State University,

San Luis Obispo, CA 93407, USA

R. W. Blake $(\bowtie)$

Department of Animal Science

and Center for Latin American and Caribbean Studies,

Michigan State University,

East Lansing, MI 48824, USA

e-mail: rwblake@msu.edu

F. I. Juárez-Lagunes • E. G. Canudas-Lara

Facultad de Medicina Veterinaria y Zootecnia,

Universidad Veracruzana,

Veracruz 91710, Mexico

\section{B. L. Rueda-Maldonado}

Instituto Nacional de Investigaciones Forestales,

Agrícolas y Pecuarias,

La Posta, Paso del Toro,

Veracruz C.P. 94277 , Mexico
}

methods and sensitivity analysis were used to identify economically viable alternatives based on expected change in milk income over feed cost (change in revenues from milk sales less change in feed costs). Herd owners in coastal Veracruz have large economic incentives, from $\$ 584$ to $\$ 1,131$ in predicted net margin, to increase milk sales by up to $74 \%$ across a three-lactation cow lifetime by improving diets based on good quality grass and legume forages. This increment is equal to, or exceeds, in value the total yield from at least one additional lactation per cow lifetime. Furthermore, marginal rates of return (change in milk income over feed costs divided by change in variable costs when alternative practices are used) of $3.3 \pm 0.8$ indicate clear economic incentives to remove fundamental productivity vulnerabilities due to chronic energy deficits and impeded growth of immature cows under typical management. Sensitivity analyses indicate that the economic outcomes are robust for a variety of market conditions.

Keywords Risk analysis · Net margin · Modeling · Tropics · Herd vulnerability $\cdot$ Alternative management

\author{
Abbreviations \\ CNCPS Cornell Net Carbohydrate and Protein System \\ INIFAP National Institute of Forestry Agriculture and \\ Livestock Research
}

\section{Introduction}

Dual-purpose cattle herds constitute an important livelihood in rural Veracruz, which is an important supplier of Mexico's 
beef and milk. However, information for improving the productivity of dual-purpose cattle systems in tropical Latin America, including Mexico, and likely in tropical agro ecosystems around the world is scarce, especially regarding the benefits and costs of alternative management strategies (Blake 2004, 2008; Magaña-Monforte et al. 2006; Absalón-Medina et al. 2011).

We addressed this problem using a modeling approach to evaluate limitations and productivity potentials from alternative nutrition management of dual-purpose herds of the Genesis farmer organization of the central coast of Veracruz, Mexico (Absalón-Medina et al. 2011). The objective of this case study is to evaluate the economic viability and incentives to farmers from alternative dietary management options to improve milk production and increase profitability, based on the cow performance outcomes predicted in our companion study.

\section{Materials and methods}

\section{CNCPS feed requirement calculations}

The Genesis farmer organization in the municipality of Medellín de Bravo, Veracruz, Mexico, its environmental setting, and forage-based management and typical animal performance are described in our companion study (Absalón-Medina et al. 2011) and in the report of Absalón-Medina (2008). Dietary information was obtained from the Instituto Nacional de Investigaciones Agrícolas y Pecuarias (INIFAP) forage database (Juárez et al. 2002a, b), which includes feedstuffs from Genesis farms. The Cornell Net Carbohydrate and Protein System model (CNCPS; v.6.0; Tylutki et al. 2008) was used to predict energy and protein requirements, feed intake, feed energy balances and probable body tissue status, and milk production for management of groups of cows specified by physiological status, parity, and each of four forage seasons (Absalón-Medina et al. 2011).

\section{Maintenance requirements}

We calculated the basal maintenance requirement for net energy in a thermal-neutral environment with minimum physical activity for $3 / 4$ Bos taurus $\times 1 / 4$ Bos indicus cows, where $\mathrm{NEm}(\mathrm{Mcal} /$ day $)=$ mean $(\text { body weight; } \mathrm{BW})^{0.75}$ times the weighted average required for the specified breeds. Based on the assumption that cows frequently mobilize $25 \%$ of body weight (tissue reserves) to support milk production (Reynoso et al. 2004; Tedeschi et al. 2004; Baba 2007), we estimated a maximum allowable BW loss of $20 \%$ of calving weight for primiparous cows and those with body condition score (BCS) $<3.0$ units. For parities $\geq 2$ and $\mathrm{BCS} \geq 3.0$, the maximum allowable BW loss was $25 \%$ of mature weight. Consequently, maintenance requirements were adjusted according to expected changes in organ mass and body weight from depressed dietary nutrient supplies, especially in the early and late dry seasons. The CNCPS model simulates these relationships by increasing or decreasing the maintenance requirement by $10 \%$ for each BCS unit above or below a score of 3 (Fox et al. 2004). The energy cost of excreting excess $\mathrm{N}$ (urea) was calculated by subtracting it from ME intake (Tylutki et al. 2008). The nighttime temperature at our study site is at the threshold $\left(20^{\circ} \mathrm{C}\right)$ allowing for the dissipation of body heat accumulated during the day. Panting is seldom observed. Therefore, potential heat stress effects were ignored. The maintenance requirement for energy expended in daily physical activity was computed for the predicted amount of time standing, number of body position changes, and distance walked (Fox et al. 2004; Tedeschi et al. 2004).

\section{Feed intake and body tissue status}

The predicted mean voluntary feed intake for each management group was determined by body weight, ambient temperature, milk production, forage quality and stage of gestation. Because Genesis cows are fed fixed amounts of supplements and non-grazed forages, these quantities were subtracted from the predicted total feed intake (Absalón-Medina et al. 2011). The difference was assumed to be the amount of forage grazed. Cows mobilized body tissue to offset the feed energy deficit in early lactation to achieve the expected average milk production (if mature), or gained body weight by repleting tissues when energy intake exceeded requirements. Gains in body weight by immature cows were assumed to comprise tissue repletion and new growth. The final pool of tissue energy and BW for cows at the end of late gestation corresponded to the expected values at next calving (AbsalónMedina et al. 2011). Subsequent BW and BCS were calculated from predicted tissue energy losses and gains (Fox et al. 2004; Absalón-Medina 2008).

Alternatives to improve current nutritional management

Our analysis (Absalón-Medina et al. 2011) identified a repeating pattern of two fundamental productivity constraints on cows of all ages and forage seasons of the year, chronic energy deficits among all dry cows in late gestation and impeded growth of young cows. Consequently, cow and herd productivity potentials were evaluated for alternative forage-based diets based on prior Genesis farmer behaviors, focusing on calvings in the early dry season (October through December), which was the most limiting season for every management group. Management alternatives were harvested grasses of good quality (especially Andropogon gayanus, or Llanero grass; Cynodon plectostachyus, or African Star grass; maize silage) to complement grazing and reduce the need for purchased supplements, and foliage 
of tree legumes (Leucaena leucocephala, Gliricidia sepium) to improve milk production with more rumen degradable nitrogen and less neutral detergent fiber. These options imply additional investments in seeds and establishment and management of legume paddocks.

\section{Economic evaluation}

Following the procedure of Rueda et al. (2003) for a Brazilian case, we applied partial budgeting methods and sensitivity analyses to assess nutritional management alternatives for Genesis farm managers. Partial budgeting analysis helps identify economically viable alternatives based on the change in profits expected from specific farm management changes (Boehlje and Eidman 1984). Our analysis considered the additional quantities and chemical composition of required feeds to obtain expected increases in milk production compared to typical (baseline) performance for each management group of cows. Economic information consisted of the prices of feeds and milk sold in 2007 (Table 1). This information was used to calculate the expected change in milk income over feed cost (IOFC; change in revenues from milk sales less change in feed costs) using alternative diets instead of typical dietary management. Supplements like poultry bedding, molasses, commercial concentrate and sugar cane bagasse typically can be obtained locally. Maize silage and Mulato hay are produced by Genesis farmers. The cost for producing improved harvested forage of good quality (e.g., Llanero hay, maize silage including ears) was assumed to be equal to the price of harvested forages in the local market. The average annual milk price of US $\$ 0.32 / \mathrm{kg}$ (range

Table 1 Market prices for dietary inputs and milk in 2007 (US\$)

\begin{tabular}{lc}
\hline Item & $\$ / \mathrm{kg}^{\mathrm{a}}$ \\
\hline Poultry bedding & 0.04 \\
Molasses & 0.14 \\
Commercial concentrate $^{\mathrm{a}}$ & 0.26 \\
Maize silage $^{\mathrm{b}}$ & 0.05 \\
Mulato hay $^{\mathrm{b}}$ & 0.05 \\
Pangola hay $^{\mathrm{c}}$ & 0.15 \\
Improved harvested forage $_{\text {Sugar cane bagasse }}$ & 0.15 \\
Legume $^{\mathrm{d}}$ & 0.02 \\
Sorghum grain $^{\text {Milk }}$ & 0.15 \\
& 0.24 \\
\end{tabular}

${ }^{\text {a }}$ Exchange rate in 2007. US $\$ 1=10.97$ Mexican pesos. Feed prices are expressed on a dry matter basis

${ }^{\mathrm{b}}$ Produced by Genesis members (Rodríguez-Morales et al. 2005)

${ }^{\mathrm{c}}$ Price of hay in commercial markets of Medellín de Bravo (El Tejar)

${ }^{\mathrm{d}}$ Gliricidia sepium or Leucaena leucocephala
\$0.26-0.36) was used to estimate revenues from milk sales. The importance of assessing the economic feasibility of alternative options relies on the accuracy of determining typical dietary management costs. Thus, we considered it important to incorporate detailed dietary management information to better understand baseline scenarios.

In addition to providing information about the profitability of management changes, the partial budgeting method facilitates calculation of the marginal rate of return (MRR). The MRR is the change in farm-level profits divided by the change in variable costs, which for our study is the change in milk income over feed costs divided by the change in variable costs (feed costs) when alternative nutritional management is undertaken. The MRR is an important indicator of potential acceptance of new practices by farmers because it accounts for both financial incentives (profits) and the potential constraints (additional costs), which frequently must be incurred prior to receipt of increased profits. New technologies familiar to farmers are more likely to be adopted when the MRR exceeds 0.5 (CIMMYT 1988).

Sensitivity analysis of alternative nutritional management options evaluates the changes necessary in the assumed milk prices or feed costs to make alternatives as profitable as current feeding practices $(\mathrm{MRR}=0)$ and to achieve the threshold for farmer interest in adoption ( $M R R=0.5)$. These sensitivity analyses were undertaken separately for decreases in the milk price, increases in improved forage and legume costs, and for a combination of a lower milk price and higher forage costs. The assumed changes in milk price and feed cost would reduce the profitability of alternative management, and suggest the degree of risk that Genesis farmers adopting alternative management might encounter. If large changes are required in milk price or feed costs to reduce the MRR to 0.0 or 0.5 , this suggests that the nutritional management alternatives are robust with regard to market conditions different than those assumed in our base economic analysis.

\section{Results and discussion}

We believe this is the first published tropical case study to evaluate economic potential from and interactions among energy balance, milk production and expected growth of dual-purpose cows. Our assessment focused on strategic scenarios where cows would receive concentrate supplementation during the dry period (improved management), or improved dietary management, beginning at first calving using improved grasses and substitution in early lactation of legume forage for poultry bedding (Table 2). Protein is especially needed at this time to complement energy supplies from the mobilization of body tissues for milk synthesis. The corresponding changes in income over feed cost were 
Table 2 Milk production, purchased feed and economic outcomes of four nutritional management alternatives for Genesis herds

\begin{tabular}{|c|c|c|c|c|c|c|c|}
\hline $\begin{array}{l}\text { Physical or } \\
\text { Economic } \\
\text { Variable }\end{array}$ & Baseline & $\begin{array}{l}\text { With } \\
\text { improved } \\
\text { nutrition }\end{array}$ & $\begin{array}{l}\text { Difference } \\
\text { from } \\
\text { baseline }\end{array}$ & $\begin{array}{l}\text { Harvested } \\
\text { grass }\end{array}$ & $\begin{array}{l}\text { Difference } \\
\text { from } \\
\text { baseline }\end{array}$ & $\begin{array}{l}\text { Improved forage } \\
\text { and legume after } \\
\text { first lactation }\end{array}$ & $\begin{array}{l}\text { Difference } \\
\text { from } \\
\text { baseline }\end{array}$ \\
\hline \multicolumn{8}{|l|}{ Physical units } \\
\hline \multicolumn{8}{|l|}{$\begin{array}{l}\text { Purchased feed, } \\
\mathrm{kg} \mathrm{DM} / \text { animal } \\
\text { lifetime }\end{array}$} \\
\hline Poultry bedding & 886 & 886 & & 886 & & & -886 \\
\hline Molasses & 1,158 & 1,158 & & 1,158 & & 1,158 & \\
\hline Concentrate & 1,323 & 1,323 & & 1,323 & & 1,323 & \\
\hline Silage & 1,272 & & $-1,272$ & 1,272 & & 1,272 & \\
\hline Mulato & 1,199 & & $-1,199$ & 1,199 & & 1,199 & \\
\hline Bagasse & 169 & & -169 & 169 & & 169 & \\
\hline Sorghum & 817 & 263 & -554 & 416 & -401 & 441 & -376 \\
\hline Improved forage & & 2,640 & 2,640 & 2,640 & 2,640 & 2,640 & 2,640 \\
\hline Legume & & & & & & 869 & 869 \\
\hline \multicolumn{8}{|l|}{ Revenues and costs } \\
\hline \multicolumn{8}{|l|}{ Revenues } \\
\hline $\begin{array}{l}\text { Milk revenues, } \\
\text { \$/animal lifetime } \\
\text { Variable costs for fee }\end{array}$ & 2,059 & 2,779 & 720 & 3,225 & 1,166 & 3,591 & 1,532 \\
\hline \multicolumn{8}{|l|}{$\begin{array}{l}\text { Purchased feed, } \\
\text { \$/animal lifetime }\end{array}$} \\
\hline Poultry bedding ${ }^{\mathrm{b}}$ & 35 & 35 & & 35 & & & -35 \\
\hline Molasses & 162 & 162 & & 162 & & 162 & \\
\hline Concentrate & 344 & 344 & & 344 & & 344 & \\
\hline Silage & 64 & & -64 & 64 & & 64 & \\
\hline Mulato & 60 & & -60 & 60 & & 60 & \\
\hline Bagasse & 3 & & -3 & 3 & & 3 & \\
\hline Sorghum $^{\mathrm{c}}$ & 196 & 63 & -133 & 100 & -96 & 106 & -90 \\
\hline Improved forage ${ }^{\mathrm{d}}$ & & 396 & 396 & 396 & 396 & 396 & 396 \\
\hline Legume $^{\mathrm{d}}$ & & & & & & 130 & 130 \\
\hline $\begin{array}{l}\text { Total variable costs } \\
\text { for feed } \\
\text { Net margin and relate }\end{array}$ & 865 & 1,001 & 136 & 1,164 & 300 & 1,265 & 401 \\
\hline $\begin{array}{l}\text { Income over feed } \\
\text { costs, \$/animal } \\
\text { lifetime }\end{array}$ & 1,195 & 1,779 & 584 & 2,061 & 866 & 2,326 & 1,131 \\
\hline $\mathrm{MRR}^{\mathrm{e}}$ & & & 4.3 & & 2.9 & & 2.8 \\
\hline
\end{tabular}

${ }^{\text {a }}$ Negative values indicate reduced usage. Positive values indicate additional input use. Milk price $=\$ 0.32 / \mathrm{kg}$

${ }^{\mathrm{b}}$ Cost per kg of dry matter $(\mathrm{DM})=\$ 0.04$

${ }^{\mathrm{c}}$ Cost per $\mathrm{kg}$ of $\mathrm{DM}=\$ 0.24$

${ }^{\mathrm{d}}$ Cost per $\mathrm{kg}$ of $\mathrm{DM}=\$ 0.15$

${ }^{\mathrm{e}}$ The marginal rate of return (MRR) equals the change in net margin divided by the change in variable costs

obtained from estimated increases (decreases) in harvested forages and sorghum grain (poultry bedding) to obtain predicted increases in lactation milk production and growth of immature cows across a three-lactation lifetime (Table 2).
Increases in net margin indicate the value of improved milking performance but do not include potential increased revenues from sales of heavier culled cows and, importantly, more calves from better dietary energy support of reproduction. 
The expected IOFC is larger than typical management from incorporating either good quality grass or grass combined with forage legume into diets appropriately supplemented with sorghum grain across the first three lactations of a cow's lifetime (Fig. 1). The corresponding large increases in IOFC, $\$ 584$ from diets relying on concentrate supplementation especially in the dry period, $\$ 866$ from diets relying on harvested grass and $\$ 1,131$ from diets relying on grass plus legume, equal or exceed in value the total yield from at least one additional lactation per cow. All the alternative management strategies had larger IOFC than current management practices used by Genesis members. Implementing these alternatives is likely to be feasible because they rely on local resources with which Genesis farmers are already familiar.

If IOFC from the first three lactations is approximately $50 \%$ of the total value of milk sales over a cow's lifetime (i.e., net margin $=0.50[6,435 \mathrm{~kg}$ milk $\times \$ 0.32 / \mathrm{kg}])$ then this strategy may be expected to increase IOFC by about $50 \%$ (concentrate supplementation during dry period) to $95 \%$ (grass + legume) compared to typical management. The MRR for the concentrate supplementation during the dry period, grass and grass + legume management strategies are 4.3, 2.9 and 2.8, respectively. Compared to the MRR of 0.5 typically required for adoption, our predicted outcome clearly suggests substantial economic incentives for farmers to reduce cow vulnerability and improve herd productivity through better diets.

Fundamentally important to this management strategy is quality control of forages (i.e., analysis and monitoring of chemical composition), cost-effective production of harvested forages, and their separate storage for feeding to management groups of cows that differ in their nutritional requirements. Furthermore, herd management depends on the effective use of a nutrition tool like the CNCPS model. The outcomes predicted in this study correspond to a monitoring protocol throughout calving intervals of cow management groups defined by forage season of calving, age of cow, and physiological stages of the calving interval.

Sensitivity analyses indicate the necessary changes in assumed milk price and cost of improved forage to achieve MRR values equal to 0.5 or 0.0 (Table 3). The milk price would have to be only 19 to $41 \%$ of the assumed mean value for the MRR to equal 0.0 and 0.5 for the three management alternatives (Table 3). All milk price values for MRR $\leq 0.5$ fall well outside of the historical range observed during this study (\$0.26-0.36 per kg). Similarly, in order to achieve a $\mathrm{MRR}=0.5$ or 0.0 improved-forage cost would have to exceed twice the assumed values. A combination of both a decrease in milk price of $50 \%$ and increases in costs of improved forage of $25 \%$ or $50 \%$ was required to achieve MRR values of 0.5 or 0.0 . These large required percentage changes in economic values indicate that the improvement in profitability from alternative nutritional management is not very sensitive to changes in the costs of the key output (milk) prices and input (improved forage) costs. Thus, our finding that these are more profitable options is likely to hold under a variety of market conditions. This also suggests that the results herein may have broader applicability in tropical regions when similar biological and economic conditions are present in dual-purpose cattle systems. An array of other nutritional management options, similar to the ones evaluated in this paper can be analyzed with nutritional tools such as the CNCPS and subsequently tested in field conditions.

\section{Farmer opportunities and bottlenecks}

Our results show substantial benefits for Genesis farmers from using alternative nutritional management under a wide variety of market conditions. However, despite these large improvements in milking performance and profitability, farmers do not invest widely in these alternatives. Thus, it is of interest to discuss the possible reasons for this and suggest strategies to overcome them. We hypothesize that the main reasons include information constraints, risk aversion and economic factors, which interact.

Because these alternative nutritional management options are little practiced, knowledge among farmers of their potential production and profitability outcomes is limited. Access to information about profitability of the alternative options may facilitate the use of alternatives about which

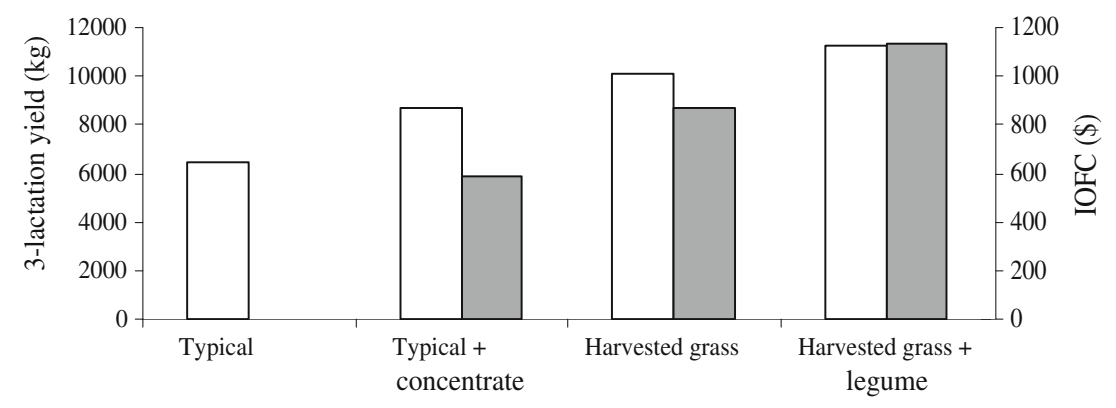

Fig. 1 Predicted three-lactation milk yields (white bars) and change in income over feed cost (IOFC; gray bars) for cows calving in the early dry season (October 1) consuming typical diets, typical diets

supplemented with concentrate during the dry period, or improved diets containing harvested grass and harvested grass plus legume from first calving 
Table 3 Sensitivity analysis of the impacts of changes in milk price, improved forage and legume costs on economic outcomes of three nutritional management alternatives for Genesis herds

\begin{tabular}{|c|c|c|c|c|c|c|}
\hline \multirow[t]{2}{*}{ Price or cost } & \multicolumn{3}{|c|}{ Value, by scenario } & \multicolumn{3}{|c|}{ Percent of base value (\%) } \\
\hline & $\begin{array}{l}\text { With improved } \\
\text { nutrition }^{\mathrm{a}}\end{array}$ & $\begin{array}{l}\text { Harvested } \\
\text { grass }{ }^{\mathrm{b}}\end{array}$ & $\begin{array}{l}\text { Improved grass } \\
\text { and legume }\end{array}$ & $\begin{array}{l}\text { With improved } \\
\text { nutrition }\end{array}$ & $\begin{array}{l}\text { Harvested } \\
\text { grass }\end{array}$ & $\begin{array}{l}\text { Improved grass } \\
\text { and legume }\end{array}$ \\
\hline \multicolumn{7}{|l|}{ Milk price } \\
\hline $\begin{array}{l}\text { Value assumed for } \\
\text { analyses in Table } 2\end{array}$ & 0.32 & 0.32 & 0.32 & 100 & 100 & 100 \\
\hline $\begin{array}{l}\text { Value required for } \\
M_{R R}{ }^{d}=0.5\end{array}$ & 0.09 & 0.12 & 0.13 & 28 & 38 & 41 \\
\hline $\begin{array}{l}\text { Value required for no } \\
\text { change in IOFC }\end{array}$ & 0.06 & 0.08 & 0.08 & 19 & 25 & 25 \\
\hline \multicolumn{7}{|l|}{ Improved forage cost } \\
\hline $\begin{array}{l}\text { Value assumed for } \\
\text { analyses in Table } 2\end{array}$ & 0.15 & 0.15 & 0.15 & 100 & 100 & 100 \\
\hline $\begin{array}{l}\text { Value required for } \\
\mathrm{MRR}=0.5\end{array}$ & 0.29 & 0.33 & 0.38 & 193 & 220 & 253 \\
\hline $\begin{array}{l}\text { Value required for no } \\
\text { change in IOFC }\end{array}$ & 0.38 & 0.48 & 0.58 & 253 & 320 & 387 \\
\hline \multicolumn{7}{|l|}{ Legume $\cos \mathrm{t}^{\mathrm{e}}$} \\
\hline $\begin{array}{l}\text { Value assumed for } \\
\text { analyses in Table } 2\end{array}$ & - & - & 0.15 & - & - & 100 \\
\hline $\begin{array}{l}\text { Value required for } \\
M R R=0.5\end{array}$ & - & - & 0.90 & - & - & 281 \\
\hline $\begin{array}{l}\text { Value required for no } \\
\text { change in IOFC }\end{array}$ & - & - & 1.46 & - & - & 456 \\
\hline \multicolumn{7}{|l|}{$\begin{array}{l}\text { Milk and improved } \\
\text { forage cost }\end{array}$} \\
\hline \multicolumn{7}{|l|}{$\begin{array}{l}\text { Value required for } \\
M R R=0.5\end{array}$} \\
\hline Milk & 0.16 & 0.16 & 0.16 & 50 & 50 & 50 \\
\hline Improved forage & 0.19 & 0.19 & 0.19 & 125 & 125 & 125 \\
\hline \multicolumn{7}{|l|}{$\begin{array}{l}\text { Value required for no } \\
\text { change in IOFC }\end{array}$} \\
\hline Milk & 0.32 & 0.32 & 0.32 & 50 & 50 & 50 \\
\hline Improved forage & 0.23 & 0.26 & 0.29 & 155 & 173 & 192 \\
\hline
\end{tabular}

${ }^{\text {a }}$ Concentrate supplementation during the dry period

${ }^{\mathrm{b}}$ Good quality grass provided since first lactation

${ }^{\mathrm{c}}$ Good quality grass and legume provided since first lactation

${ }^{\mathrm{d}}$ The marginal rate of return (MRR) equals the change in net margin divided by the change in variable costs

${ }^{\mathrm{e}}$ Empty cells (-) means not analyzed because legume is not fed in this nutritional management alternative

farmers are already aware, especially when the alternatives can be perceived to be more risky than current practices. This information could be provided through educational workshops and, if resources are available to support it, through application of these alternatives on Genesis members' farms. Even when information is available and farmers would undertake the new practices, other economic factors may constrain their ability to do so.

Although the management options analyzed here suggest that over the course of a cow's lifetime the economic returns are large, it is typical for the additional costs (e.g., for improved forage production) to precede the additional revenues (e.g., from additional milk sales). This suggests that either cash flow or credit constraints may be important limits on the adoption of new technologies. Another potential constraint is the ability of the current milk marketing system to accept increased milk production if nutritional management options are more broadly practiced by Genesis farmers. Our analysis assumes that the current milk marketing system has the capacity for additional production with limited reductions in the milk price. Assessment of these constraints can be a useful focus for subsequent work in the region.

In addition to the constraints mentioned above, information about forage quality is a fundamental constraint to nutritional management. Genesis farmers, unlike most 
dual-purpose producers in Mexico, have invested to obtain more forage of better quality (e.g., maize silage, quality hay), even though production is insufficient compared to requirements based on predictions from the CNCPS. There is a lack of timely, reasonable-cost forage analysis services, which limits knowledge about the current situation and potential options described by Absalón-Medina et al. (2011). This is another reason why improvement of diet quality via forages might be perceived as risky.

Role of modeling using ex ante evaluation

Recent work has acknowledged the role of modeling in the scientific process to be critical, especially in situations where simulation modeling could provide guidelines and potential ranges for outcomes under alternatives that have not yet (or cannot be easily) been evaluated (Tedeschi et al. 2011; Nicholson et al. 2011). Our intention in this study was to use modeling as a basis for prediction and biological and economic evaluation when much observational information currently is unavailable and would be costly to obtain. Based on the available information and previously developed models, we were able to generate biological outcomes consistent with those typically observed in this region, which is an essential component of model evaluation (Sterman 2000). However, our results may differ from performance reported for other tropical regions due to differences in assumptions or actual production conditions.

Finally, ex ante economic assessment of increased nutrient intake is both relevant and important because increasing production per animal is not always a more profitable management option. Moreover, economic conditions (like the prices of inputs and outputs) tend to be highly variable and what is profitable at one point in time may not be under alternative market conditions. Thus, economic analysis coupled with sensitivity analysis is a useful approach for assessment of management options under time-varying economic conditions.

\section{Conclusion}

Findings in our companion study (Absalón-Medina et al. 2011) pinpointed key biological (energetic) and management limitations in dual-purpose cattle herds in the central coastal region of Veracruz. Energetic deficits signified less total milk per cow productive lifetime, which could be addressed through appropriate investments to improve forage quality with proper nutritional management.

High-quality harvested forage increased milk yields by about one-third over typical management. When diets from first parturition properly supported cow growth and tissue repletion to obtain desirable body weights, milk production in second and third lactations was improved about $60 \%$.
Judiciously supplemented diets that also incorporated legume forages starting at first calving were predicted to further increase productivity by about $80 \%$ (i.e., from group management with CNCPS monitoring and properly supplemented diets with good forage quality).

The changes in lactation performance and IOFC from incorporating into properly supplemented diets either good quality harvested grass or grass combined with forage legume resulted in large increases in net margin across a threelactation cow lifetime ( $\$ 866$ and $\$ 1,131)$. The estimated marginal rates of return on these strategies substantially exceed thresholds usually required for farmers to have interest in adoption.

Based on the available information, Genesis farmers, and probably many other dual-purpose herd owners in coastal Veracruz, apparently have large economic incentives to increase herd incomes by implementing nutritional management strategies like those considered in this study. These strategies may also have potential in other similar agro ecosystems in the tropics. However, this information apparently is difficult to put into practice. Important factors may have been omitted from our partial budget analysis, such as conversion costs, equipment to be purchased, additional labor, and knowledge constraints. Future research is needed to assess these factors to better anticipate the ultimate impacts from alternative management.

Acknowledgments The authors thank the Instituto Nacional de Investigaciones Forestales, Agrícolas y Pecuarias, Facultad de Medicina Veterinaria y Zootecnia at Universidad Veracruzana, and the Centro de Previsión del Golfo de México for providing data and information for this study. Special thanks are extended to the Genesis producer association for their cooperation and facilitation of information gathering. In addition, the authors acknowledge financial support from the Department of Animal Science, Cornell University and Higher Education for Development through a US-Mexico Training, Internships, Exchanges and Scholarships grant (http://tiesmexico.cals.cornell.edu/).

Open Access This article is distributed under the terms of the Creative Commons Attribution Noncommercial License which permits any noncommercial use, distribution, and reproduction in any medium, provided the original author(s) and source are credited.

\section{References}

Absalón-Medina, V. A., 2008. Productivity limitations and potentials for dual-purpose cow herds in the central coastal (leeward) region of Veracruz, Mexico. Unpublished MS thesis, Cornell University. http://tiesmexico.cals.cornell.edu/research/ documents/victor_absalon_masters_thesis.pdf

Absalón-Medina, V. A., Blake, R. W., Fox, D. G., Juárez-Lagunes, F. I., Nicholson, C. F., Canudas-Lara, E. G., Rueda-Maldonado, B. L., 2011. Limitations and potentials of dual-purpose cow herds in central coastal Veracruz, Mexico. Tropical Animal Health and Production. Submitted.

Baba, K., 2007. Analysis of productivity, nutritional constraints and management options in beef cattle systems of eastern Yucatan, Mexico: A 
case study of cow-calf productivity in herds of Tizimin, Yucatan. Unpublished MS thesis, Cornell University. http://tiesmexico.cals. cornell.edu/research/documents/kotaro_baba_ms_thesis_20061212. pdf

Blake, R. W., 2004. Dairy cattle performance in difficult environments. In: Proceedings of the 7th World Bruna Conference, Fieragricola, Verona, Italy, 125-131.

Blake, R. W., 2008. Perpectivas de la Investigación Pecuaria en el Mundo Tropical: Utilización de Recursos Genéticos de Ganado Bovino. En: C. V. Durán y R. Campos (eds), Perspectivas de Conservación, Mejoramiento y Utilización de Recursos Genéticos Criollos y Colombianos en los Nuevos Escenarios del Mejoramiento Animal. Universidad Nacional de Colombia, Palmira, páginas $1-17$.

Boehlje, M. D., and V. R. Eidman. 1984. Farm Management. Wiley, New York.

CIMMYT. 1988. Agronomic Data to Farmer Recommendations: Economic Training Manual. Centro Internacional de Mejoramiento de Maíz y Trigo, Texcoco, México.

Fox, D. G., Tedeschi, L. O., Tylutki, T. P., Russell, J. B., Van Amburgh, M. E., Chase, L. E., Pell, A. N., Overton, T. R., 2004. The Cornell net carbohydrate and protein system model for evaluating herd nutrition and nutrient excretion. Animal Feed Science and Technology, 112, 29-78.

Juárez, F. I., Montero, M., Serna, C., Alpírez, F., y Canudas, E. G., 2002a. Evaluación nutricional de gramíneas forrajeras tropicales para bovinos en el centro del estado de Veracruz. Unpublished report, Instituto Nacional de Investigaciones Forestales, Agrícolas y Pecuarias.

Juárez, F. I., Montero, M., Serna, C., Alpírez, F., y Canudas, E. G., 2002b. Evaluación nutricional de leguminosas tropicales para bovinos de doble propósito. Unpublished report, Instituto Nacional de Investigaciones Forestales, Agrícolas y Pecuarias.

Magaña-Monforte, J. G., Ríos-Arjona, G., y Martínez-González, J. C., 2006. Los sistemas de doble propósito y los desafíos en los climas tropicales de México. Archivo Latinoamericano de Producción Animal, 14, 105-114.
Nicholson, C. F., L. O. Tedeschi y A.C.G. Lellis Viera, 2011. Aplicación de Modelos en el Estudio de Sistemas Dinámicos para Mejorar la Rentabilidad y Sostenibilidad de los Sistemas de la Producción Ganadera en América Latina. En: C. V. Durán y R. Campos (eds), Segundo Simposio Internacional en Genómica y Modelación de los Nuevos Escenarios de la Ganadería Bovina Tropical. Universidad Nacional de Colombia, Palmira, páginas 147-177.

Reynoso, O., Fox, D. G., Blake, R. W., Barry, M. C., Tedeschi, L. O., Nicholson, C. F., Kaiser, H. M., Oltenacu, P. A., 2004. Predicting nutritional requirements and lactation performance of dualpurpose cows using a dynamic model. Agricultural Systems, 80, 67-83.

Rodríguez-Morales, J. M., Montero, D., Marín, L., Velásquez, F., 2005. GGAVATT Génesis; evaluación técnica y económica. En: Desarrollo de Proyectos Agropecuarios Integrales (DPAI), comité operativo estatal.

Rueda, B. L., Blake, R. W., Nicholson, C. F., Fox, D. G., Tedeschi, L. O., Pell, A. N., Fernandez, E. C. M., Valentim, J. F., Carneiro, J. C., 2003. Production and economic potentials of cattle in pasturebased systems of the western Amazon region of Brazil. Journal of Animal Science, 81, 2923-2937.

Sterman, J.D., 2000. Business Dynamics: System Dynamics Modeling for a Complex World. Irwin/McGraw-Hill, Boston.

Tedeschi, L. O., Fox, D. G., Guiroy, P. J., 2004. A decision support system to improve individual cattle management: 1. A mechanistic, dynamic model for animal growth. Agricultural Systems, 79, 171204.

Tedeschi, L. O., C. F. Nicholson and E. Rich., 2011. Using the System Dynamics modelling approach to develop management tools for animal production with emphasis on small ruminants. Small Ruminant Research, 98:102-110.

Tylutki, T. P., Fox, D. G., Durbal, V. M., Tedeschi, L. O., Russell, J. B., Van Amburgh, M. E., Overton, T. R., Chase, L. E., Pell, A. N., 2008. Cornell net carbohydrate and protein system: a model for precision feeding of dairy cattle. Animal Feed Science and Technology, 143, 174-202. 